\title{
Study on the Variation of Annual Runoff and Influencing Factors in Kuye River during the Past 60 Years
}

\author{
MA Zhihua, GUO Qiaoling, SU Ning \\ Institute of resource \& Environment, Henan Polytechnic University, Jiaozuo 454003,China
}

\begin{abstract}
In this study, observed runoff series from a hydro-station respectively named Wenjiachuan station in the Kuye river was manipulated for monthly annual variation analysis assisted by using nonuniformity coefficient and concentration degree(period).the cumulative filter methods was employed to detect the trend of inner-annual runoff. Based on meteorological and hydrological data of the Wenjiachuan hydrologic station from 1955 to 2015, the paper studied the variation tendency, the abrupt and periodic changes of annual runoff using the Mann-Kendall non-parametric test and accumulation anomaly curve. Double mass curve was used to estimate the impact of human activities and climate change on the runoff variation. The curve of seasonal runoff distribution for Wenjiachuan station appeared two peak patterns. The annual runoff declined markedly, the effect of climate on runoff decreased, the influence of human activities on runoff gradually increased the human activities are the primary factors leading to the reduction of annual runoff. In human activities, large-scale water and soil conservation measures and high-strength coal mining have produced significant effects on the annual runoff reduction in Kuye River.
\end{abstract}

Keywords: runoff reduction; variation trend; influence factor; Kure River

\section{Introduction}

The river runoff is a main link of water cycle. The variation of runoff plays a leading role in the evolution of the whole hydrological system, and has a significant impact on the resource environment and regional economy ${ }^{[1]}$. The coupling effect of natural processes and human activities make the underlying surface pattern in the direction and extent changes, and then exert a profound influence on runoff evolution process and its temporal and spatial distribution and finally resulted in significant impact on the storage and circulation of water resource $^{[2]}$. The Kuye River is located in the Loess Plateau, water-wind erosion crisscross region, situated in arid and semi-arid transition zone, and the ecological environment is extremely fragile ${ }^{[3]}$. Large area implementation of soil and water conservation measures and the exploitation of coal resources, which has greatly changed the underlying surface conditions in basin, produced great hydrological effects, runoff processes occurred significant changes, and even emerged the serious phenomenon of setting off. This situation threatened the sustainable development of the ecological environment and the economic in the basin. Based on this, the paper selects the Kuye River nmbasin export control Wenjiachuan Hydrologic Station measured runoff data and meteorological data to analysis the runoff variation trends and evolution characteristics in the river basin and explore the driving factors on runoff change from two aspects of climate change and human activities which is useful for understanding the eco-hydrological process under the background of soil and water conservation comprehensive management and coal mining, while provides scientific basis for reasonable development and configuration of water resources .

\section{General situation of study region and data sources 2.1 General situation of study region}

Kuye River is the middle reaches of the Yellow River estuary town -- Longmen interval of the first grade tributary in the right bank, and originates from Dongsheng of Inner Mongolia Autonomous Region City, Palestinian Scheduled ditch. And in Shamoutou Village, Wenjiachuan Township, Shenmu Country, Shaanxi Province empties into the Yellow River ${ }^{[6]}$. The main stream is 242 meters long, and the basin area is about 8706 square kilometers ${ }^{[7]}$. Affected by the continental monsoon, the basin shows that drought and less rain in spring, more rainstorm in summer, frost and freezing early in autumn, cold and less snow in winter ${ }^{[8]}$. Basin underlying surface condition is complex. The upstream is the area of sandy steppe, in the middle and lower reaches is gully region of loess plateau where the soil is loose. Kuye River is a coarse sandy tributary that water and soil erosion serious in the middle reaches of the Yellow River. The coal resources within the basin is rich. The famous Shenfu Dongsheng large coalfield run through the middle part of the basin, the mining area accounts for $28.51 \%$ of the whole basin's total area ${ }^{[9]}$, and the coal resource has the characteristics of buried shallow, easy exploitation, good quality and so on. Until 2010, the coal output has reached 1.24 billion tons ${ }^{[10]}$. 


\section{2 sources of date}

Wenjiachuan hydrologic station is the export control station of Kuyehe basin, and the catchment area is $8645 \mathrm{~km}^{2}$, which account for more than $99 \%$ of the Kuye River Basin's area. And its runoff change can basically reflect the actual changes in the entire basin runoff. The analysis of runoff, precipitation, evaporation and other data are derived from the actual observation data of Wenjiachuan hydrologic station.

\section{Research methods}

\subsection{The annual runoff analysis method}

1) Mann-Kendall test. Mann-Kendall trend test is a non-parametric statistical test method. The advantage is that no sample is required to conform to a certain distribution, nor is it affected by a few outliers. In recent years, the trend analysis of the hydrological time series has been widely applied in the literature ${ }^{[11]}$ In this study, the Mann-Kendall test was used to analyze the change trends of precipitation, evaporation and runoff at different periods.

2) Double cumulative curve. The double cumulative curve method is the simplest and the most direct method to analyze the consistency of the hydrological and meteorological elements or the long-term trend ${ }^{[14]}$. The basic idea is two variables according to the same length of time gradually accumulate, a variable is abscissa, another variable is ordinate, the inflection points can be used as the basis of analysis of variable phase change. When it affected by human activities, rainfall-runoff double cumulative curve will shift, but according to the s curve skewed to determine the underlying surface is influenced by human activities intensity, reveal the impact of human activities on runoff changes periodically.

\subsection{Distribution of annual runoff characteristics}

(1)Inhomogeneity. By climate factors such as precipitation, air temperature changes in seasonal effect, the runoff supply also appear obvious seasonal change, determines the distribution of runoff years along with the change of season a cyclical and inhomogeneity ${ }^{[15]}$. There are lots of methods of studying annual runoff distribution characteristics. In this paper mainly uses annual runoff distribution non-uniformity coefficient and annual runoff distribution in the fully accommodation coefficient ${ }^{[16]}$ to analyze the runoff of years changes.

Annual runoff distribution non-uniformity coefficient $\mathrm{C}_{\mathrm{v}}$ is calculated by the following formula.

$$
C_{V}=\sigma / \frac{1}{R}=\sqrt{\frac{1}{12} \sum_{i=1}^{12}\left(R_{i}-\bar{R}\right)^{2}} /\left(\frac{1}{12} \sum_{i=1}^{12} R_{i}\right)
$$

In this formula: where $\mathrm{R}_{\mathrm{i}}$ represents monthly runoff in the year (hundred million $\mathrm{m}^{3}$ ); $\overline{\mathrm{R}}$ represents monthly mean runoff (hundred million $\mathrm{m}^{3}$ ); $\delta$ represents mean square deviation. From formula (1), it is clear that a higher $\mathrm{C}_{\mathrm{v}}$ number indicates the monthly runoff disparity, and the more uneven distribution of annual runoff.

Annual runoff distribution in the fully accommodation coefficient $C_{r}$ is another annual distribution index. The calculation formula is as follows:

$$
C_{r}=\sum_{i=1}^{12} \Psi(t)(R(t)-\bar{R}) / \sum_{i=1}^{12} R(t) \quad \Psi(t)=\left\{\begin{array}{l}
0, R(t)<\bar{R} \\
1, R(t) \geq \bar{R}
\end{array}\right.
$$

Where $\mathrm{R}_{\mathrm{i}}$ represents monthly runoff (hundred million $\mathrm{m}^{3}$ ); represents monthly mean runoff (hundred million $\mathrm{m}^{3}$ ).

(2)Concentration degree and concentration period. Concentration degree and concentration period are the two important indices. They use the monthly runoff to reflect the concentration degree of annual runoff and the appearing time of the maximum runoff ${ }^{[17]}$. It regards the monthly runoff as a vector, the size of the monthly runoff and the month as the length and direction of a vector respectively ${ }^{[18]}$. Each month from January to December of the azimuth Angle respectively as $0^{\circ}, 30^{\circ}, 60^{\circ}, \ldots, 360^{\circ}$ and the monthly runoff is decomposed into both $\mathrm{x}$ and $\mathrm{y}$ Component direction, the $\mathrm{x}$ and $\mathrm{y}$ directions on vector synthesis are:

$$
\left\{\begin{array}{l}
R_{x}=\sum_{i=1}^{12} r_{i} \sin \theta_{i} \\
R_{y}=\sum_{i=1}^{12} r_{i} \cos \theta_{i} \\
R=\sqrt{R_{x}^{2}+R_{y}^{2}}
\end{array}\right.
$$

$r_{i}$ and are the size and direction of the monthly runoff; $R_{x}$ and $R_{y}$ are the $X, Y$ directions synthesis vector; $R$ is the 
total synthesis vector of $R_{x}$ and $R_{y}$.

Concentration degree $\mathrm{RCD}_{\text {year }}$ and concentration period $\mathrm{RCP}_{\text {year }}$ defined as follows:

$$
P C D_{\text {year }}=\sqrt{R_{x}^{2}+R_{y}^{2}} / R_{\text {year }} \quad P C P_{\text {year }}=\arctan \left(R_{x} / R_{y}\right)
$$

The formula shows that concentration degree $\left(\mathrm{PCD}_{\text {year }}\right)$ reflects the concentrated runoff accounted for the proportion of total annual runoff, concentrated period $\left(\mathrm{PCP}_{\text {year }}\right)$ approximately represents the appearing time of the maximum runoff in a year.

(3) Variation amplitude. The change amplitude of runoff was measured by two indexes of relative change amplitude and absolute change amplitude ${ }^{[19]}$. The formula is as follows:

$$
\begin{aligned}
& C_{m}=Q_{\max } / Q_{\min } \\
& \Delta Q=Q_{\max }-Q_{\min }
\end{aligned}
$$

Where $C_{m}$ and represent the relative variation range and the absolute variation range; $Q_{\max }$ and $Q_{\min }$ are the maximum and minimum monthly runoff during the year, respectively.

\subsection{Monthly runoff variation trend}

The cumulative filter method was used to fully reflect the qualitative trend of monthly runoff. Principle is as follows ${ }^{[20]}$.

$$
S=\left(\sum_{i=1}^{k} \frac{R_{i}}{k}\right) / \bar{R}
$$

Where $\mathrm{S}$ is cumulative average; $\mathrm{R}_{\mathrm{i}}$ are hydrological time series values; is the average hydrological time series; $\mathrm{k}=1,2,3, \ldots, \mathrm{n}(\mathrm{n}$ is the length of the series), $\mathrm{i}=1,2,3, \ldots, \mathrm{k}$.

\section{Result analyses}

\section{1 annual Runoff variation analyses \\ 4.1.1 Analysis of runoff variation trend}

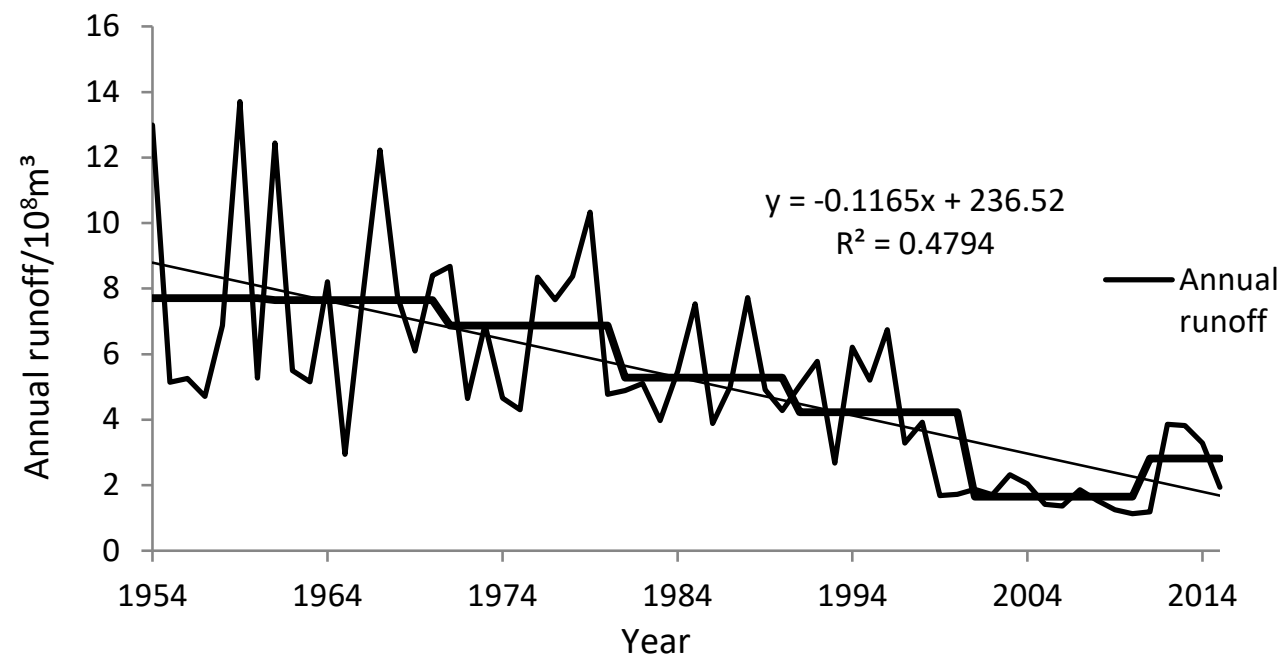

Fig.1 Trend of annual streamflow in Wenjiachuan station

In the past 60 years, the runoff of Kuye river not only presents the normal fluctuation between the interannual period, but has a trend of decreasing year by year (Figure 1). The annual runoff linear decline rate of Wenjiachuan Station is about $0.1165 \times 108 \mathrm{~m}^{3} / 10$ a. It presents the extreme abundance of runoff in 1959 , while the exceeding low value of runoff appears at 2010, and this two extreme D-value is $12.576 \times 10^{8} \mathrm{~m}^{3}$. The average value of annual runoff in the 50s,60s,70s,80s,90s in twentieth Century and the early twenty-first Century in turn was $7.71 \times 10^{8} \mathrm{~m}^{3}, 7.64 \times 10^{8} \mathrm{~m}^{3}, 6.86 \times 10^{8} \mathrm{~m}^{3}, 5.27 \times 10^{8} \mathrm{~m}^{3}, 4.23 \times 10^{8} \mathrm{~m}^{3}, 2.04 \times 10^{8} \mathrm{~m}^{3}$, and the runoff at the end of $70 \mathrm{~s}$ and the end of 90s presented the phenomenon of sharply reduced. At the beginning of the twenty-first Century, the mean value of runoff was only $38.9 \%$ in the multi-year average value, and it was $24.9 \%$ in 1950 s. In order to more clearly distinguish the stage variation of interannual runoff, the annual runoff cumulative departure curve of Wenjiachuan station was drawn from 1965 to 2015 (Fig.2). The annual runoff mainly experienced 3 stages of change: In 1965-1978, the annual runoff was increasing in the overall trend; the annual runoff showed a slight decrease trend from 1979 to 1997; and in 1998-2015, the runoff decreased significantly. 


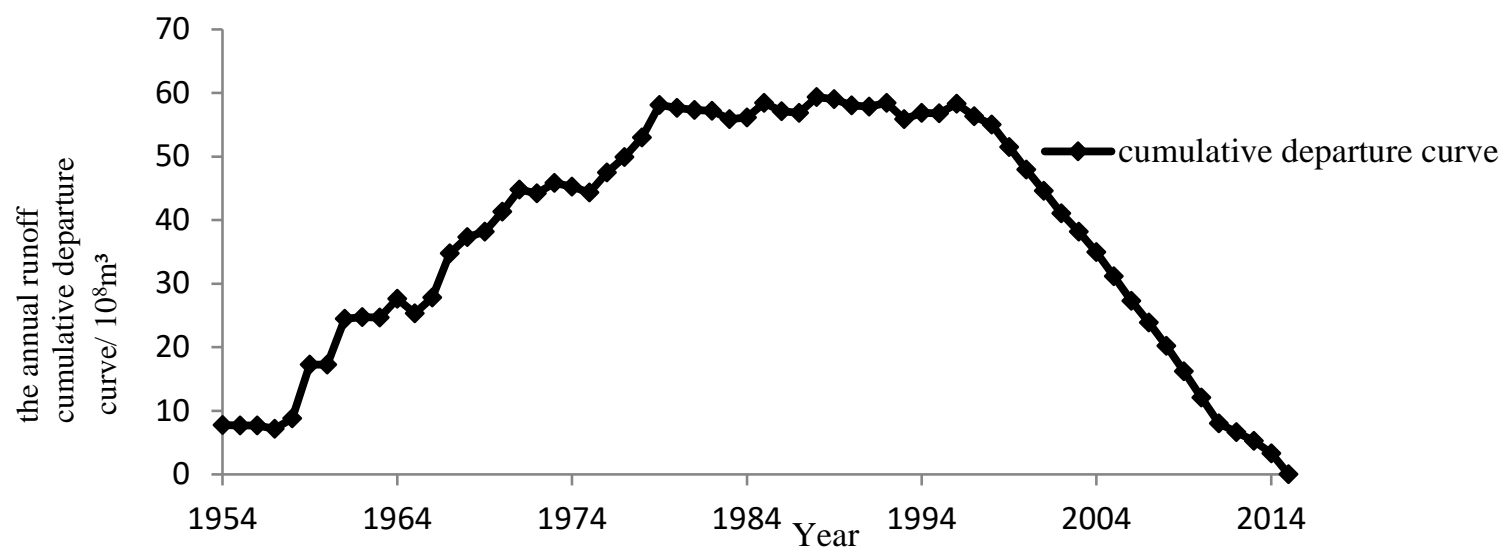

Fig.2 The accumulation anomaly curve of runoff series in Wenjiachuan station

\subsubsection{The analysis of influencing factors of annual runoff variation}

Both natural and human factors cause the change of hydrological process in basin, which is the main factor to analyze the evolution of river runoff. The natural factors of the Kuye river basin mainly consider the precipitation and evaporation, the artificial factors mainly consider coal mining, water and soil conservation measures, production and domestic water consumption.

(1) Effects of climate on Runoff

Throughout the study period, the mean values of precipitation and evaporation were $400.56 \mathrm{~mm}$ and $1086.5 \mathrm{~mm}$, the maximum values were $692.6 \mathrm{~mm}$ and $1366.4 \mathrm{~mm}$, and the minimum were $138.7 \mathrm{~mm}$ and $884 \mathrm{~mm}$. The extreme ratios were 4.99 and 1.55, annual variation was not significant, which indicating that the precipitation and evaporation of wet and low water changes in Kuye River are not severe and relatively uniform. Combined with the previous mutation point analysis, the annual runoff, precipitation and evaporation in different periods were tested by M-K rank correlation test (Table 1). Under the significant level of $\alpha=0.05$, in 1955-1978, the runoff was increased to a certain extent, but the $Z_{c}$ value is not through the significant test; the precipitation has a certain increase, $Z_{c}$ also did not pass the significance test; the evaporation showed a decreasing trend, and $Z_{c}$ did not through the test of significance. In 1979-1997, both the runoff and precipitation showed a decreased tendency, and the $Z_{c}$ values were not pass the significance test. The evaporation decreased significantly, and the through the significant test. In 1998-2015, both the evaporation and precipitation showed a increased tendency when the $Z_{c}$ values of precipitation and runoff did not pass the significance test, and $Z_{c}$ of evaporation through the significance test and the runoff showed a decreasing trend the values were not pass the significance test, which indicated that the influence of climatic factors on runoff was gradually weakened.

Tab.1 M-K test of the annual runoff, precipitation and evaporation series in Wenjiachuan station

\begin{tabular}{|c|c|c|c|c|c|c|c|}
\hline \multirow{2}{*}{ periods } & \multirow{2}{*}{$\begin{array}{c}\text { Sequence } \\
\text { length }\end{array}$} & \multicolumn{2}{|c|}{ Runoff } & \multicolumn{2}{|c|}{ Precipitation } & \multicolumn{2}{|c|}{ Evaporation } \\
\hline & & Zc & significance & $\mathrm{Zc}$ & significance & $\mathrm{Zc}$ & significance \\
\hline $1955-1978$ & 24 & 0.023 & Not significant & 0.174 & Not significant & -0.719 & Not significant \\
\hline 1979-1997 & 19 & -0.07 & Not significant & -0.280 & Not significant & -1.015 & significant \\
\hline 1998-2015 & 18 & -0.454 & Not significant & 0.985 & Not significant & 5.757 & significant \\
\hline $1955-2015$ & 61 & -6.038 & significant & -0.218 & Not significant & -2.763 & significant \\
\hline
\end{tabular}

(2) Impact of human activities on Runoff

Coal mining is the main reason for the reduction of runoff in Kuye River. The exploitation of coal in the basin began in the late 1970s. By 1991, the output of raw coal in the basin reached $6.26 \times 106 \mathrm{t}$, and was $1.73 \times 108 \mathrm{t}$ in 2011, which was 27.59 times as much as in 1991. The development of coal industry has accelerated the decay of river runoff. A large number of coal mines along the upstream Wulanmulun River have been exploited. Coal mining has changed the hydrogeological conditions; the runoff yield, confluence, supply, runoff and discharge of water resources have been changed; and the groundwater storage has been destroyed ${ }^{[22]}$, which reduced the hydraulic gradient between the underground water level and the water level. In addition, coal mined-out area collapsed and water-conducting fissures communicated with riverbeds, which resulting in loss of surface water resources and reduced river runoff ${ }^{[23]}$. According to statistics, in 2001-2005, Kuye River zero runoff are more than 100 days in every year. In 2000 - 2008, the annual average runoff decreased by 71.5\% compared with 1956 - 2010.

Soil and water conservation has a significant impact on river runoff by changing the runoff yield and confluence mechanism and hydrological cycle ${ }^{[24]}$. Soil and water loss in the Kuye River Basin is serious. The 
main water and soil conservation measures include terraced fields, silt-dams, afforestation, grass planting and so on. According to statistics, the area of water and soil conservation accounted for only $2 \%$ of the basin area in the end of 1960s, in the end of 90s, it increased to 7\%, while it rose to $40 \%$ rapidly in 2008 . Large-scale soil and water conservation measures have resulted in the change of watershed hydrology. The sharp reduction of runoff and the increase of the area of governance have obvious consistency ${ }^{[6]}$.

In addition to coal mining and soil and water conservation measures have great influence on the runoff of Kuye River, and other activities related to the production and life also have a certain impact on runoff. Shenmu County, which taking the Kuye River as water supply and accounting for more than $50 \%$ of the watershed area, the industrial water consumption increased by nearly 10 times from 1980 to $2015^{[25]}$. In recent years, The widespread phenomenon of river sand mining, the large and uneven potholes in the channel are not conducive to runoff formation. Along with the economic development of the river basin, a lot of Water surface landscape and urban green space appeared in the town along the river course such as Shenmu county, Wulanmulun town and Kangbashi district, which increased the evaporation loss and irrigation water ${ }^{[10]}$, and it would be have a certain influence on runoff.

(3) Quantitative analysis of the impacts of climate and human activities on Runoff

The double accumulation curve of precipitation and runoff can be used to analyze the stage change of the influence of human activities on runoff. Fig.5 shows the precipitation-runoff double accumulation curve at Wenjiachuan station, and the curves are obviously deflected in 1979 and 1998. Combined with the previous accumulation distance analysis results and the actual investigation of human activities in the basin, the runoff series was divided into three periods: the base period (1955-1978), the general impact period of human activities (1979-1997) and the strong influence period of human activities (1998-2015). The regression equations of cumulative precipitation $\sum P$ and cumulative runoff $\sum R$ in the base period are established by regression analysis of cumulative precipitation and cumulative runoff in the base period: $\sum R=0.0173 \sum P+4.1275\left(R^{2}=\right.$ 0.9969), Based on the annual precipitation and annual runoff data during the base period, the correlation equation of precipitation and runoff in the base period is established: $\mathrm{R}=0.114 \mathrm{P}+28.98$, According to the annual precipitation and annual runoff correlation equation of Wenjiachuan station, the theoretical average runoff in different periods is calculated, and the value can be regarded as the approximate value of the natural runoff. The difference between the measured value of the base period and the calculated value of each period is the influence value of the precipitation change on the runoff. The difference between the measured value of the base period and the measured value of each period minus the influence value of precipitation change is the variation of human activities to runoff. Table 2 shows the effects of precipitation and human activities on runoff at different time periods. The influence of human activities on runoff is increasing from $38.27 \%$ (the general impact period)to $90.81 \%$ during the whole study period, and become the dominant factors of Kuyehe river runoff decrease. While the effect of precipitation on runoff decreased rapidly from $61.73 \%$ to $9.19 \%$, and the effect on runoff is weakening day by day.

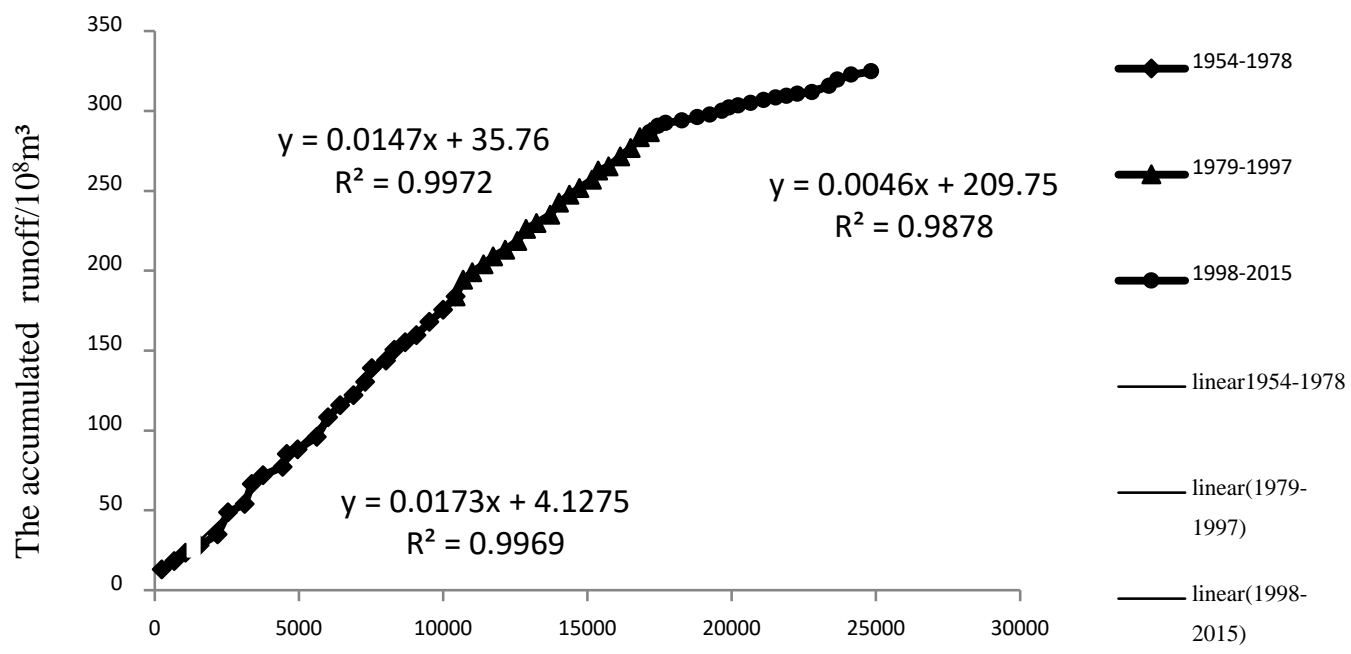

The accumulated rainfall $/ 10^{8} \mathrm{~m}^{3}$

Fig.5 Double mass curve for annual rainfall streamflow in Wenjiachuan station 
Tab.2 Influences of precipitation and human activities on the Kuye River runoff

\begin{tabular}{|c|c|c|c|c|c|c|c|c|}
\hline \multirow[b]{2}{*}{ period } & \multirow{2}{*}{$\begin{array}{l}\text { precipitat } \\
\text { ion(mm) }\end{array}$} & \multicolumn{2}{|c|}{ Runoff $\left(\times 10^{8} \mathrm{~m}^{3}\right)$} & \multirow{2}{*}{$\begin{array}{c}\text { Total } \\
\text { reduction }\end{array}$} & \multicolumn{2}{|c|}{ Precipitation } & \multicolumn{2}{|c|}{ Human activity } \\
\hline & & $\begin{array}{l}\text { calculated } \\
\text { value }\end{array}$ & $\begin{array}{c}\text { measured } \\
\text { value }\end{array}$ & & $\begin{array}{c}\text { influence } \\
\text { value }\left(\times 10^{8} \mathrm{~m}^{3}\right)\end{array}$ & $\begin{array}{c}\text { influence } \\
\text { rate(\%) }\end{array}$ & $\begin{array}{c}\text { influence } \\
\text { value }\left(\times 10^{8} \mathrm{~m}^{3}\right)\end{array}$ & $\begin{array}{c}\text { influence } \\
\text { rate(\%) }\end{array}$ \\
\hline $1955-1978$ & 419.53 & & 7.47 & & & & & \\
\hline 1979-1997 & 356.63 & 6.10 & 5.25 & 1.821 & 1.37 & 61.73 & 0.85 & 38.27 \\
\hline $1998-2015$ & 413.24 & 6.98 & 2.09 & 4.644 & 0.49 & 9.19 & 4.89 & 90.81 \\
\hline $1979-2015$ & 400.35 & 6.53 & 3.67 & 3.80 & 0.94 & 24.67 & 2.86 & 75.33 \\
\hline
\end{tabular}

\subsection{Distribution of monthly runoff}

\subsubsection{Distribution of monthly runoff}

The distribution of annual runoff in Wenjiachuan station is extremely uneven. Since 1960s, the distribution of annual runoff in Wenjiachuan station (Table 1 and Finger 1). From 1960 to 2015, the average annual runoff in Wenjiachuan stations was 5.24billion $\mathrm{m}^{3}$. The monthly runoff reached a maximum in August. In this station, the largest monthly runoff, respectively, accounting for annual runoff of 25.5\%; the smallest monthly runoff, respectively, accounting for annual runoff of 2.25\%; the biggest monthly runoff, respectively 11.4 times as large as the smallest monthly runoff. In Wenjiachuan, the maximum runoff for three consecutive months also appeared from July to September, accounting for annual runoff of $53.56 \%$. The minimum runoff for three consecutive months appeared from December to February, accounting for annual runoff of $8.89 \%$, only for former's $16.59 \%$.The annual runoff distribution for this station appeared two peak pattern. The runoff reached a minimum in January, began to rise in February. As temperatures rise, snow melt water supply formed spring flood, runoff reaches a peak in March, and then began to decline in April, until June upward trend again, the highest peak occurs during the year in August, and thereafter is gradually reduced until a low value is reached again in December.

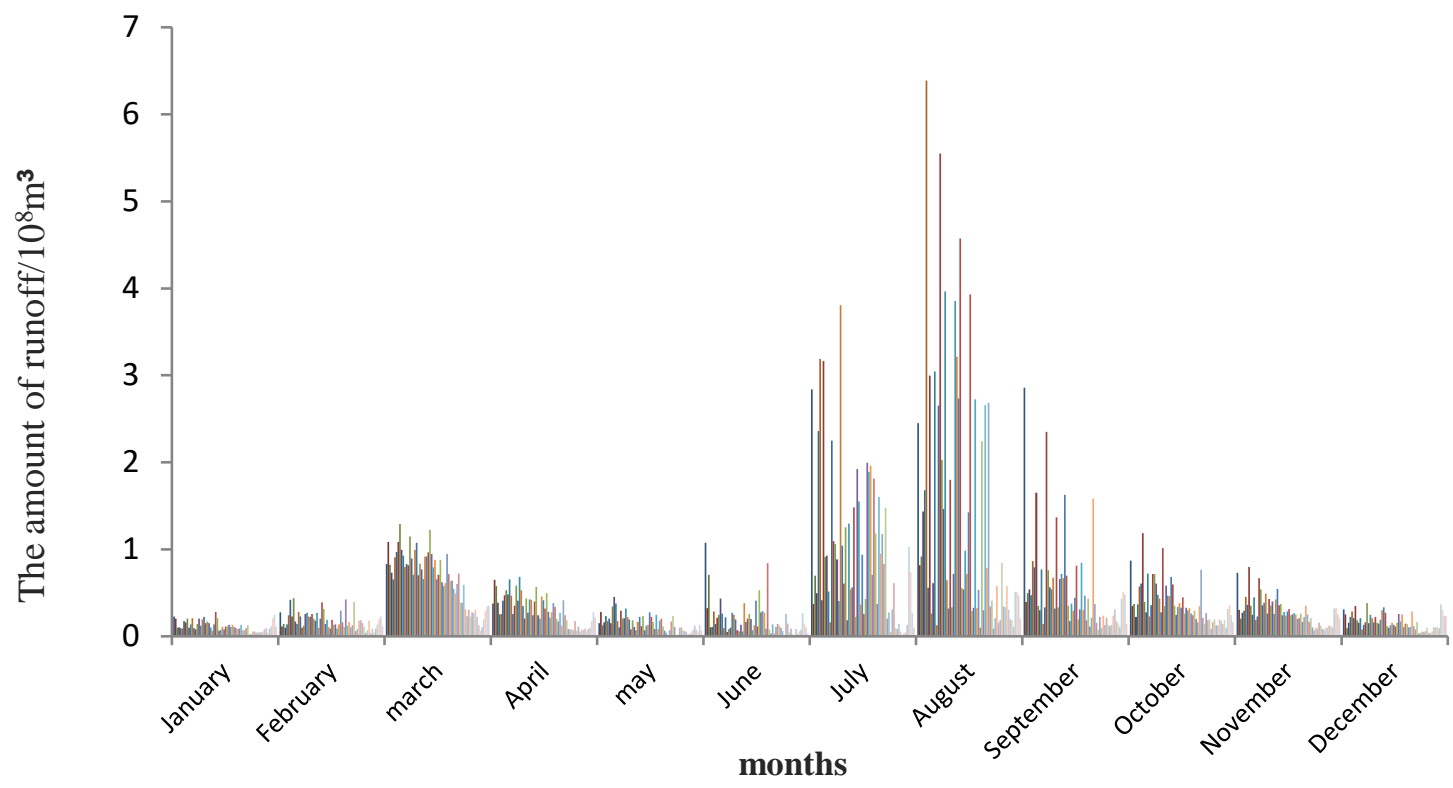

Fig.1 Distribution of annual runoff in Kuye River(Wenjiachuan)

Tab.1 Statistic characteristics of annual runoff distribution in Kuyehe River(Wenjiachuan)( 108m3,\%)

\begin{tabular}{cccccccccccc}
\hline \multirow{2}{*}{ Year } & \multirow{2}{*}{$\begin{array}{c}\text { Annual } \\
\text { runoff }\end{array}$} & \multicolumn{2}{c}{ July- Sept. } & \multicolumn{2}{c}{ Dec.- February } & \multicolumn{2}{c}{ March-April } & \multicolumn{2}{c}{ August } & \multicolumn{2}{c}{ January } \\
\cline { 3 - 10 } & runoff & percent & runoff & percent & runoff & percent & runoff & percent & runoff & percent \\
\hline $1954-1959$ & 8.12 & 4.88 & 60.1 & 0.52 & 6.46 & 1.26 & 15.47 & 2.28 & 28.11 & 0.14 & 1.67 \\
$1960-1969$ & 7.33 & 3.87 & 52.77 & 0.59 & 8.03 & 1.44 & 19.61 & 1.93 & 26.32 & 0.15 & 2.04 \\
$1970-1979$ & 7.23 & 4.09 & 56.61 & 0.62 & 8.52 & 1.25 & 17.30 & 2.21 & 30.64 & 0.16 & 2.22 \\
$1980-1989$ & 5.36 & 2.48 & 46.27 & 0.37 & 6.92 & 1.04 & 19.50 & 1.27 & 23.79 & 0.11 & 2.06 \\
$1990-1999$ & 4.48 & 2.41 & 53.75 & 0.43 & 9.54 & 0.86 & 19.10 & 1.01 & 22.49 & 0.09 & 2.09 \\
$2000-2009$ & 1.71 & 0.72 & 41.99 & 0.23 & 13.56 & 0.37 & 21.92 & 0.37 & 21.92 & 0.05 & 3.21 \\
$2010-2015$ & 2.54 & 1.02 & 40.21 & 0.49 & 19.39 & 0.38 & 14.82 & 0.33 & 13.06 & 0.13 & 5.28 \\
$1954-2015$ & 5.24 & 2.80 & 53.56 & 0.47 & 8.89 & 0.97 & 18.55 & 1.34 & 25.5 & 0.12 & 2.25 \\
\hline
\end{tabular}

\subsubsection{Distribution of annual runoff characteristics}

The calculation results of non-uniformity coefficient(Cv), fully accommodation coefficient(Cr), concentration 
degree(PCD), concentration period(PCP), the relative variation range $(\mathrm{Cm})$ and the absolute variation $(\Delta \mathrm{Q})$ range of Wenjiachuan station(Table 2).

From annual distribution non-uniformity coefficient, in time.The non-uniformity coefficient of Wenjiachuan station reached a maximum in 1970s, while this hitted the lowest in 2000s. From 1960s to 1990s, its value is maintained at 0.8 above, by the early 21st century, they dropped to 0.52 rapidly. This shows that in Kuye River basin runoff distribution in the various periods of the 20th century is uneven, and it has become relatively uniform in the early 21st century in Kuye River basin. From different periods, the runoff series was divided into three periods: the base period (1955-1978), the general impact period of human activities (1979-1997) and the strong influence period of human activities (1998-2015).In the Wenjiachuan station, the non-uniformity coefficient of the base period and the general impact period of human activities more close to 1 than the strong influence period of human activities, It shows that the first two periods were more homogeneous. The aspect of fully accommodation coefficient, the first two periods were more than the strong influence period of human activities. It shows that the uneven distribution of runoff during the year of the first periods were stronger than the last period, the distribution of the year is more concentrated than the last period.

As for annual runoff distribution concentration degree, the concentration degree of this station is stable at 0.3 above from 1960 s to 1990 s, but the numbers are only 0.16 respectively in the early $21^{\text {th }}$. In 1970 s, the concentration degree is the largest; secondly, it's 1960 s and 1990s; the minimum number from $21^{\text {th }}$ century. In terms of the concentration period, the maximum runoff time of wenjiachuan station has been relatively close in the middle of July to the middle of August.The concentration period of Wenjiachuan station in 1970s and early 2000s, delayed 0 days, 4days and 19days than the annual mean value (July 29), respectively. However, in the 1950s, 1960s, 1980s, 1990s, the runoff concentration period occurs advanced 4 days, 2days, 10days and 7days than annual mean value, respectively. The maximum difference of the maximum runoff appearing time in different periods is 19days.

Tab. 2 Statistic characteristics of annual runoff distribution in Kuyehe River(Wenjiachuan)

\begin{tabular}{|c|c|c|c|c|c|c|c|}
\hline \multirow[b]{2}{*}{ Year } & \multirow[b]{2}{*}{$\mathrm{C}_{\mathrm{v}}$} & \multirow[b]{2}{*}{$\mathrm{C}_{\mathrm{r}}$} & \multirow[b]{2}{*}{$\mathrm{PCD}_{\text {year }}$} & \multicolumn{2}{|c|}{ PCP } & \multirow[b]{2}{*}{$\mathrm{Cm}$} & \multirow[b]{2}{*}{$\begin{array}{c}\Delta \mathrm{Q} \\
\left(10^{8} \mathrm{~m}^{3}\right)\end{array}$} \\
\hline & & & & $\begin{array}{l}\text { Direction of } \\
\text { composition } \\
\text { vector }\end{array}$ & $\begin{array}{l}\text { Maximum } \\
\text { runoff time }\end{array}$ & & \\
\hline 1954-1959 & 1.02 & 0.43 & 0.41 & 200.8 & July 25 & 25.1 & 2.4 \\
\hline 1960-1969 & 0.95 & 0.36 & 0.3 & 205.6 & July 27 & 20.25 & 2.07 \\
\hline 1970-1979 & 1.16 & 0.37 & 0.35 & 209.7 & July 29 & 24.19 & 2.58 \\
\hline 1980-1989 & 1.09 & 0.36 & 0.3 & 189.1 & July 19 & 19.03 & 1.75 \\
\hline 1990-1999 & 1.08 & 0.38 & 0.32 & 194.03 & July 22 & 34.78 & 1.45 \\
\hline 2000-2009 & 0.89 & 0.31 & 0.16 & 215 & August 2 & 17.82 & 0.43 \\
\hline 2010-2015 & 0.52 & 0.19 & 0.19 & 232.43 & August 17 & 8.17 & 0.42 \\
\hline $1953-2015$ & 0.95 & 0.34 & 0.29 & 208.8 & July 29 & 21.33 & 1.78 \\
\hline
\end{tabular}

\subsubsection{Monthly runoff trend}

Affected by many factors, such as climate change and human activities, the monthly distribution of the measured runoff in Kuye River basin changed, the cumulative filter methods shows (Fig. 2)that the January and February runoff of wenjiachuan station has significantlydecreased in the late 1950s.The runoff of Wenjiachuan in July in the early 1960s has slight fluctuations, after that time ,it is always in decline. The trend of runoff in March and April is similar. Their runoff in the late 1950s is on the rise, peaked in 1956, the early 1960s were obviously volatile and then gradually decreased,but the trend of runoff in April was bigger thanMarch ; the trends of runoff inJune, September and October were similar, before the 1970s, they had a large reduction rate, and then they had a steady decrease in the state and the curve was relatively flat,after a little fluctuation in the late 1970s, the trend of runoff in october was a steady decline.In the late 1950s ,the runoff fluctuatewas a bir strong in May, a peak in 1964, after the $70 \mathrm{~s}$ in the stable reduce state;Runoff fluctuations in August was a bit strong, after the $80 \mathrm{~s}$ in a state of steady decrease. Except that , the rest monthly runoff shows that they had little volatility in the late 1970s and the early 1980s,but they were basically in a state of steady decrease in the rest time. 

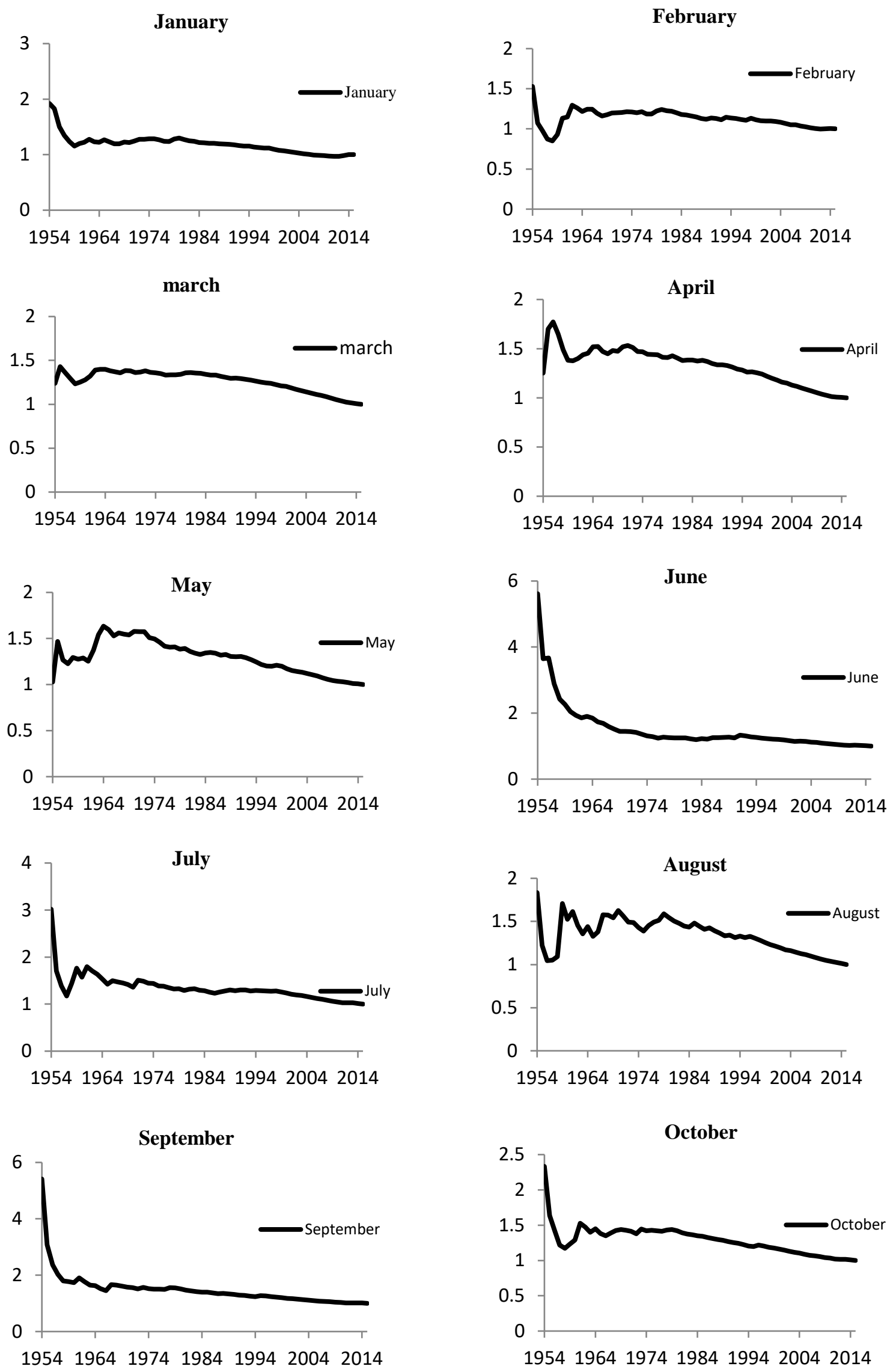

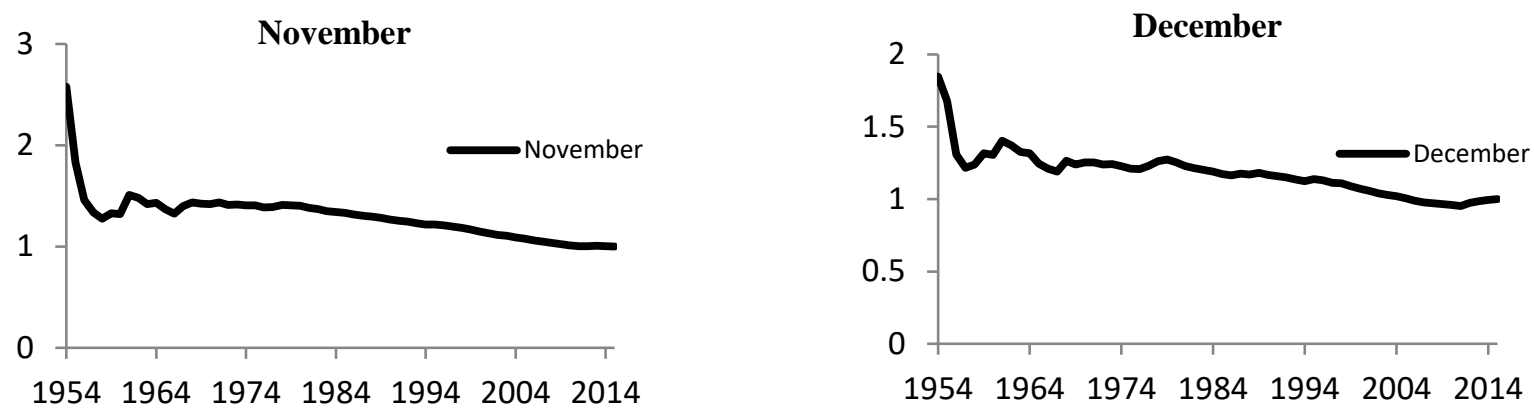

Fig. 2 Accumulative average curves of the monthly runoff for key stations in

Kuyehe River (Wenjiachuan)

\section{Discussions}

(1) The annual runoff of Kuye River had mutations in 1979 and 1998 respectively. The decrease of runoff in 1979 was related to the natural factors, and on the other hand, the large-scale implementation of soil and water conservation measures and the increase of industrial and urban water use which began in the end of 1970s also has the relation too. In 1998, the runoff again reduced significantly in addition to the above factors, and the large-scale coal mining was also closely related in the end of 1990s. According to the statistics, the annual average exploitation of the Kuye River was about $29 \times 10^{4} \mathrm{t}$ in the 1980 s, and increased to $520 \times 10^{4} \mathrm{t}$ in the 1990 s. In the first five years of the 21 st century, it increased rapidly to $5452 \times 10^{4} \mathrm{t}$.

(2) The significant reduction of annual runoff in the Kuye River is a result of the combined effect of climate change and human activities. Climate change is a relatively slow process, and the effect of human activities on runoff is rapid, which has become the dominant factor affecting runoff reduction. Therefore, it is necessary to strengthen the management and guidance of human activities in the watersheds, and make it towards a favorable direction.

(3) The double cumulative curve analyzes the impact of climate change and human activities on runoff, and only considering the precipitation, without considering the temperature, evaporation and other meteorological factors, so the accuracy of the results is affected to a certain extent. At the same time, this method cannot separate the influence quantity of the different types of human activities, this problem should be the emphasis and difficulty for the future research.

(4) Kuye River basin is located in arid and semi-arid regions in the middle Yellow River. It's runoff mainly recharged by precipitation and snow melt water. Based on annual runoff distribution, ice and snow melt water supply in spring will lead to a small flood process, and when precipitation increases sharply during the flood season, the largest flood peak appears.

(5) A large number of coal mining in Kuye River mainly located Wenjiachuan station. Wenjiachuan station was located in the downstream of the mining area. After 1980s, with the booming of coal mining, the monthly runoff was significantly reduced greatly .Coal mining became the main reason for reducing the runoff of Kuye River. Caused by exploitation of coal resources, Kuye River water resources reduce accounted for $54.8 \%$ of the runoff change from 1997 to 2006 Jiang et al.2010 ${ }^{[26]}$.

(6) In this study, we only used some common indexes to analysis the annual runoff distribution characteristics and the change law at present. You can see that there is a certain correlation between the indexes, and they reflects the annual runoff distribution characteristics from different aspects. In order to understand and master the annual runoff distribution characteristics more accurately and scientifically, we should carry out more appropriate way to enrich annual runoff distribution research.

(7) The change of annual runoff distribution is caused by climate change and human activities. This paper mainly analyze the annual runoff distribution change of Kuye River, as for how to identify different elements' quantitative influence on the change of annual runoff distribution, it need to be further in-depth study. Meanwhile, the change of annual runoff distribution directly affected the economic, social and ecological safety of the people in the basin. Thus, the impact of changes in annual runoff distribution effects on socio-economic and ecological environment isWorthy of further study.

\section{Conclusions}

(1)In the past 60 years, the high and low water change of annual runoff in Kuye river has been more severe, and the linear decline rate of Wen jiachuan station is about $1.165 \mathrm{~m}^{3} / 10 \mathrm{a}$, which shows a significant decrease 
trend in the whole. And the catastrophe points occurred respectively in 1959 and 2015.

(2)According to the analysis of the precipitation-runoff double cumulative curve: Compared with the base period, the impact of climate change of the general impact period of human activities on the reduce of runoff is greater than the impact of human activities on runoff. The strong influence period of human activities is mainly affected by human activities, even in the case of a slight rise in annual precipitation, the annual runoff is significantly reduced. The influence rate of climate change on runoff reduction decreased from $61.73 \%$ (the general influence period of Human activities) to $9.19 \%$, while the influence rate of corresponding human activities on runoff reduction increased from $38.27 \%$ to $90.81 \%$.

(3)The annual runoff distributions observed by the Wenjiachuan hydro-stations show a "two-peak pattern" distribution. As the temperature rose up in the spring, snow and ice melting water supplied soon. So, the first peak appeared in March. Afterwards, precipitation increased in flood season. This caused the second peak in August which is obviously higher than the peak in March.

(4)The annual runoff distribution of Kuye River is very uneven. Form 1960s to 1990s, the indexes are significantly greater than early $21^{\text {th }}$ century. It shows that the annual runoff distribution in Kuye River basin is uneven in various periods of the 20th century. But the annual runoff distribution in the early 21st century is relatively uniform.

(5)As for annual runoff distribution concentration period, the maximum runoff of Wenjiachuan station occurs time focus on late July to early August. The maximum difference of the maximum runoff appearing time in different periods is 29days in Wenjiachuan station.

(6)The runoff of each month of Wenjiachuan hydro-stations respectively have different variation trend. Before the 1970s, the monthly runoff of February, April ,May and August were more obvious than other months. It show that the Wenjiachuan station more significantly affected by human activities.

\section{References}

[1] CHEN Xin-hua, GUO Qiao-ling, CHEN Zhi-hui. The runoff variation characteristics and influencing factors in Beiniuchuan River [J].Journal of Arid Land Resources and Environment, 2015, 29 (5): 186-191.

[2] LIU Er-jia,ZHANG Xiao-ping,ZHANG Jian-jun. Variation of Annual Streamflow and the Effect of Human Activity in the Kuye River during 1956 to 2005[J].Journal of Natural Resources, 2013,28(7):1159-1168.

[3] FAN Nian-nian, XUE Xiao-ni. Analysis on sediment movement characters in the Kuye River [J].Journal of Sediment Research, 2010, 35 (2):75-80.

[4] LEI Yong-nan,ZHANG Xiao-ping,ZHANG Jian-jun. Change trends and driving factors of base flow in Kuye River Catchment[J].ACTA ECOLOGICA SINICA,2013,33(5): 1559-1568.

[5] GUO Qiao-ling, CHEN Xin-hua,LIU Pei-wang. Variation of Runoff and Influence of Human Activity Rate in Kuye River Basin[J].Bulletin of Soil and Water Conservation, 2014,34(4):110-117.

[6] WANG Guo-qing, ZHANG Jian-yun, LI Yan. Analysis of runoff evolution and factor of driving force in Kuye river Catchment [J].Journal of Water Resources and Water Engineering, 2014, 25 (2):7-16.

[7] GUO Qiao-ling, HAN Zhen-ying, YANG Lin-jie. Hydrological simulation of impacts of coal mining on surface runoff in Kuye River[J].Advances in Science and Technology of Water Resources, 2015,35(4):19-23.

[8] ZHAO Xiao-kun,WANG Sui-ji,FAN Xiao-li. Analysis on the change trend of runoff and influence factors in Kuye river basin from 1954 to 1993[J].Journal of Water Resources and Water Engineering, 2010,21(5):32-36.

[9] LIU Xiao-qiong, LIU Yan-sui, LI Tong-sheng. Changes and reduction causes of annual runoff in intensive energy development area: a case study of Kuye river[J].Journal of Lanzhou University(Natural Sciences, 2014,50(3):299-303.

[10] BAI Le, LI Huai-en, HE Hong-mou. Analysis on detection and attribution of runoff change in KUye river basin [J].Journal of Hydroelectric Engineering, 2015,34 (2):15-21.

[11]SU He, KANG Wei-dong,CAO Zhen-zhen. Analysis on precipitation and runoff change trend from 1954 to 2009 in Kuye river basin [J].Ground water, 2013, 35 (6):14-17.

[12] Shakure Tahir, Hamid Yimit, Mamattursun Eziz. Research on period of annual runoff in Kaidu river based on wavelet analysis [J].Research of Soil and Water Conservation, 2014, 21 (1):142-146.

[13] XI Xiu-mei, LIU Hai-long. Relationship between annual runoff of the mainstream of Tarim river and sunspots activity[J].Progress in Geography, 2013,32(6):880-885.

[14] MU Xing-min,ZHANG Xiu-qin,GAO Peng. Theory of double mass curves and its applications in hydrology and meteorology [J].Journal of China Hydrology, 2010, 30 (4):47-51.

[15]YAN Hua-yun,YANG Gui-lin, WANG Qing-chun. Analysis of the variation law of the distribution of the distribution of the Yangtze river source in the year [J]. Glacial Permafrost,2006,28( 4):526-529.

[16]ZHANG Yu, TANG Ying-feng, HAN Ke-ming, et al. Analysis of the distribution of distribution in the river basin of Tao river[J]. Dry Area Resources and Environment,2011,25( 9) :71-74. 
[17]YANG Yuan-dong. The calculation method of the distribution of river and river runoff in the year[J] Journal of Geographical,1984,39( 2) :218-227.

[18]WANG Jin-xing,ZHANG Jian-yun,LI YAN, et al. In the past 50 years, the trend of the distribution of the six major drainage areas in China has changed [J]. Progress of Water Science,2008,19(5) : 656-661.

[19]YANG Ming-jin, ZHANG Bo,WANG Hai-qing, et al. Analysis of the change of mountain runoff in Heihe river basin from 1950 to 2004[J]. Resources science,2009,31( 3): 413-419.

[20] LI Xian-bin, DING Jing, LI Hou-qiang. Wavelet analysis of hydrological time series[J].Advances in Water Science, 1999,10(2):144-149.

[21] HUANG Lei, ZHANG Zhi-shan, WU Pan. Wavelet analysis of the precipitation time series in Shapotou desert area [J].Journal of Lanzhou University (Natural Sciences), 2010, 46 (5):63-66.

[22] JIANG Xiao-hui,GU Xao-wei,HE Hong-mou. The influence of coal mining on water resources in the Kuye river basin[J].Journal of Natural Resources, 2010,25(2):300-307.

[23] LV Xin, WANG Shuang-ming, YANG Ze-yuan. Influence of coal mining on water resource: a case study in Kuye river basin [J].Coal Geology and Exploration, 2014, 42 (2):54-57.

[24] XU Jian-hua, LI Xiao-yu, CHEN Jian-jun, et al. Impact of Water Conservancy and Water Conservation Project on Rainstorm, Flood and Sediment which located in the region of Hekou Town to Longmen Section of the Yellow River Middle Reaches[M]. Zhengzhou: The Yellow River Water Conservancy Press,2009.

[25] WU Xi-jun,LI Huan-en,DONG Ying. Quantitative identification of coal mining and other human activities on river runoff in northern Shanxi region [J].Acta Scientiae Circumstantiae, 2014, 34 (3):772-779.

[26] JIANG Xiao-hui, GU Xiao-wei, HE Hong-mou.Study on the influence of coal mining on water circulation in grotto river basin [J]. Journal of Natural Resources,2010, 25 ( 2):300-307. 